\title{
UPAYA MENINGKATKAN MOTIVASI BELAJAR SISWA DENGAN MENGGUNAKAN PENDEKATAN PEMBELAJARAN SIMULASI DIGITAL SISWA KELAS X TKJ DI SMK SWASTA HARAPAN BANDAR PULO KECAMATAN BATANG SERANGAN KABUPATEN LANGKAT
}

\author{
${ }^{1}$ Rantika Pratiwi, ${ }^{2}$ M. Dian Wahyudi ${ }^{3}$ Syahran Yusuf \\ Mahasiswa STKIP Budidaya Binjai \\ ${ }^{1}$ rantikapratiwi2@gmail.com \\ Dosen STKIP Budidaya Binjai \\ 2diahdian88@gmail.com \\ Dosen STKIP Budidaya Binjai \\ 3pasya22062@gmail.com
}

\begin{abstract}
ABSTRAK
Penelitian ini bertujuan untuk mengetahui peningkatan motivasi belajar siswa pada mata pelajaran Simulasi Digital dengan menggunakan pendekatan metode simulasi pada siswa kelas X TKJ SMK Swasta Harapan Bandar Pulo Kecamatan Batang Serangan. Jenis penelitian yang dilakukan yaitu penelitian tindakan kelas (classroom action research) menggunakan metode simulasi digital. Penelitian yang dilakukan ini terdiri dari dua siklus dimana setiap siklus meliputi perencanaan tindakan, observasi, dan refleksi. Subyek penelitian ini yaitu siswa kelas X TKJ yang berjumlah 27 siswa. Objek dalam penelitian ini merupakan upaya meningkatkan motivasi belajar siswa dengan menggunakan metode pembelajaran simulasi digital khususnya pada pokok bahasan branding dan presentasi video pada simulasi digital. Hasil penelitian menunjukan bahwa persentase motivasi belajar siswa pada siklus I dan siklus II dapat meningkatkan motivasi belajar siswa dengan menggunakan metode simulasi digital siswa kelas X TKJ SMK Swasta Harapan Bandar Pulo Kecamatan Batang Serangan Kabupaten Langkat. Hal ini ditunjukan dari "Meningkatkan motivasi belajar siswa dengan nilai rata-rata siklus I sebesar 40,48\%: siklus II Sebesar 45,48\%, jadi motivasi belajar siswa dalam siklus I dan siklus II sebesar 85,96\%.
\end{abstract}

Kata Kunci : Motivasi, Belajar, Siswa, Simulasi.

\section{ABSTRACT}

This study aims to determine the increase in student motivation in Digital Simulation subjects using the simulation method approach in class X TKJ TKJ SMK Swasta Harapan Bandar Pulo, Batang Serangan District. This type of research is classroom action research using digital simulation methods. This research consisted of two cycles where each cycle included action planning, observation, and reflection. The subjects of this study were 27 students of class $X$ TKJ. The object of this research is an effort to increase student motivation by using digital simulation learning methods, especially on the subject of branding and video presentations on digital simulations. The results showed that the percentage of student motivation in cycle I and cycle II can increase student motivation by using digital simulation methods for class X TKJ SMK Swasta Harapan Bandar Pulo, Batang Serangan District, Langkat Regency. This is shown from "Increasing student learning motivation with an average value of $40.48 \%$ in cycle I: cycle II of $45.48 \%$, so student motivation in cycle I and cycle II is $85.96 \%$.

Keywords: Motivation, Learning, Students, Simulation. 


\section{PENDAHULUAN}

Pendidikan merupakan faktor yang menentukan kesejahteraan manusia sehingga dapat digunakan sebagai indikator kemajuan suatu bangsa dan Negara. Semakin tinggi kualitas pendidikan suatu bangsa dan Negara maka dapat dipastikan semakin maju dan sejahtera bangsa dan Negara tersebut. Oleh karena itu, diperlukan perhatian khusus yang diajukan dalam perkembangan dan kemajuan pendidikan guna meningkatkan mutu dan kualitas pendidikan. Pendidikan juga merupakan upaya pengembangan potendi anak didik. Selanjutnya mutu sistem tergantung pada mutu komponen yang membentuk sistem, serta proses yang berlangsung hingga membuahkan hasil (Wahyudi, 2015:3). Pendidikan ini dapat dirumuskan dari sudut normatif, karena pendidikan menurut hakikatnya memang sebagai suatu peristiwa yang memiliki norma.

Sekolah Menengah Kejuruan (SMK) merupakan salah satu lembaga kejuruan yang memiliki tugas mempersiapkan peserta didiknya untuk dapat bekerja pada bidangbidang tertentu. SMK merupakan lanjutan pendidikan dasar yang memiliki tujuan utama untuk menyiapkan tenaga kerja sesuai dengan tuntutan kerja. Dalam era globalisasi dimana pekerjaan sulit didapatkan. SMK juga dituntut harus mampu menghasilkan lulusan yang berkualitas, yang berakselerasi dengan kemajuan ilmu pengetahuan dan teknologi agar lulusannya mampu bersaing dan memperebutkan lowongan pekerjaan yang ada.

Motivasi merupakan kecenderungan siswa dalam melakukan kegiatan belajar yang didorong oleh hasrat untuk mencapai hasil dan tujuan tertentu. Apabila seseorang memiliki motivasi untuk belajar maka siswa tersebut dengan baik melakukan aktifitas belajar yang lebih baik dari sebelumnya. Motivasi siswa dapat meningkatkan keinginan siswa belajar.

Motivasi belajar adalah faktor psikis yang bersifat non-intelektual. Peranannya yang khas adalah dalam hal penumbuhan gairah, merasa senang dan semangat untuk belajar. Dengan demikian, motivasi belajar adalah sebuah sesuatu yang mendorong siswa untuk berperilaku yang menyebabkan muncul perilaku dalam belajar. Siswa akan melakukan suatu proses belajar betapapun beratnya jika siswa memiliki motivasi yang tinggi, maka motivasi siswa tidak akan berkurang. Motivasi belajar memegang peranannya yang cukup besar terhadap pencapaian hasil belajar siswa. Tanpa adanya motivasi belajar siswa tidak bisa belajar. Siswa sudah tahu apa yang diingkinkan. Siswa juga sudah mempunyai cita-cita. (Rahman, 2011:75)

Motivasi belajar siswa kelas X TKJ di SMK Swasta Harapan Bandar Pulo masih tergolomg rendah. Pelaksanaan pembelajaran pada SMK Harapan Bandar Pulo masih menggunakan metode dan media seadanya. Kurangnya pemanfaatan media dalam proses pembelajaran membuat peserta didik kurang semangat dalam belajar sehingga motivasi belajar yang di dapat oleh peserta didik rendah.

Upaya yang dilakukan oleh guru untuk meningkatkan motivasi belajar siswa adalah pembelajaran simulasi digital. Simulasi merupakan sebuah cara untuk menduplikasi/penggambaran mengenai ciri, tampilan maupun karakteristik dan sistem nyata. Ide awal simulasi merupakan untuk dapat menirukan suatu sistematis nyata, kemudian dapat mempelajari mengenai sifat dan juga karakteristik operasional. Dari penjelasan diatas, dapat disimpulkan bahwa simulasi digital merupakan pembelajaran dengan pemanfaatan teknologi komputer yang 
berbasis web. Penelitian ini bertujuan untuk meningkatkan motivasi belajar dalam mata pelajaran simulasi digital pada kelas X TKJ SMK Harapan Bandar Pulo tahun ajaran 2019/2020. (Sumiati dan Asra, 2018:99)

Menurut (Sardiman, 2017:75) Motivasi merupakan suatu pendorong dari dalam individu untuk melakukan suatu tindakan dengan cara tertentu sesuai dengan tujuan yang direncanakan. Motivasi ini merupakan suatu alat kejiwaan untuk bertindak sebagai daya gerak atau daya dorong untuk melakukan pekerjaan. Dengan demikian, tanpa adanya motivasi maka pekerjaan yang ingin dikerjakan tidak akan terlaksana. Oleh karena itu, tanpa adanya motivasi belajar bagi siswa, maka siswa yang ingin belajar tidak ada dorongan atau daya gerak bagi siswa dari diri sendiri atau dari orang lain. Jadi siswa memiliki motivasi belajar itu dari dirinya sendiri dan dapat dibantu oleh guru juga orang tua agar siswa lebih termotivasi dalam pembelajaran.

Simulasi digital merupakan mata pelajaran yang membekali siswa agar dapat mengomunikasikan gagasan atau konsep melalui media digital. Dengan alat tersebut, berbagai kerugian atau kecelakaan yang mungkin dapat ditimbulkan jika langsung melakukan latihan pada situasi yang sebenarnya, bisa dikurangi. (Wina Sanjaya, 2011: 159)Dalam proses pembelajaran, siswa dapat mengomunikasikan gagasan atau konsep yang dikemukakan dengan orang lain dan mewujudkannya melalui presentasi digital, dengan tujuan untuk menguasai teknik mengomunikasikan gagasan atau konsep.

Sekolah merupakan tempat pendidikan formal yang mempunyai visi dan misi dalam membangun bangsa dan Negara melalui anak didiknya, yaitu siswa. Banyak cara yang ditempuh sekolah dalam meningkatkan motivasi belajar siswa. Diantaranya melalui perbaikan media dan metode pembelajaran sekolah serta peningkatan kualitas guru. Guru memiliki peranan yang penting dalam proses pembelajaran. Pelaksanaan belajar mengajar dikelas harus dapat memberikan kenyamanan bagi siswa. Guru harus pandai dalam mengendalikan keadaan kelas pada saat proses belajar berlangsung, selain itu guru harus pandai dalam memilih metode pembelajaran. Metode pembelajaran yang tepat dapat memberikan sikap yang positif bagi siswa. Sikap positif yang ada pada siswa dapat menumbuhkan motivasi dalam belajar siswa. Hal ini sesuai dengan konsep motivasi intrinsik yaitu mengidentifikasi tingkah laku seseorang yang merasa senang terhadap sesuatu; apabila siswa menyenangi kegiatan itu, maka termotivasi untuk melakukan kegiatan tersebut. (Uno B. Hamzah, 2010: 7)

Sekolah SMK Swasta Harapan Bandar Pulo merupakan sekolah menengah kejuruan yang terletak di jalan kwala Sawit Dusun Bandar Pulo, Desa Sei Musam, Kecamatan Batang Serangan, Kabupaten Langkat. Sekolah ini merupakan sekolah yang sudah berdiri pada tahun 2005, sehingga sarana dan prasarana yang ada belum mencukupi bagi siswa dalam mendukung proses belajar. Dengan demikian guru sebagai sentral dalam mengantarkan siswa mencapai motivasi belajar yang harus memberikan variasi dalam proses pembelajaran. Proses belajar mengajar di SMK Swasta Harapan Bandar Pulo berdasarkan pengamatan peneliti selama melakukan penelitian di bulan februari di sekolah tersebut, peneliti menemukan berbagai kendala dalam pembelajaran.

Seiring dengan pesatnya perkembangan ilmu pengetahuan dan teknologi di bidang simulasi digital terutama pada dunia industri, maka secara tidak langsung memberikan pengaruh pada perkembangan proses pembelajaran di tingkat satuan pendidikan SMK terutama di bidang keahlian TKJ yang 
menerapkan mata pelajaran simulasi digital. Dengan demikian peneliti bermaksud meneliti bagaimana "Upaya Meningkatkan Motivasi Belajar Siswa Dalam Menggunakan Pendekatan Simulasi Digital".

\section{METODOLOGI PENELITIAN}

Penelitian ini merupakan penelitian tindakan kelas atau disebut Penelitian Partisipan. Subjek dalam penelitian ini adalah siswa kelas X TKJ di SMK Swasta Harapan Bandar Pulo Batang Serangan. Objek penelitian merupakan meningkatkan motivasi belajar siswa pada pendekatan pembelajaran simulasi digital siswa kelas $\mathrm{X}$ TKJ di SMK Swasta Harapan Bandar Pulo. Menurut Arikunto (2006: 58) Penelitian tindakan kelas mempunyai tujuan yaitu memperbaiki mutu praktik pembelajaran dikelasnya. Teknik pengumpulan data dalam penelitian tindakan kelas ini dilakukan dengan pengamatan dikelas (observasi). Menurut Zainal (2009: 63) lembar observasi digunakan sebagai panduan pada pengamatan motivasi belajar dan keterlaksanaan pembelajaran simulasi digital yang dilakukan guru selama kegiatan pembelajaran berlangsung. Wawancara dengan guru dan siswa. Wawancara ini dilakukan secara tatap muka untuk memproses pembelajaran yang dilakukan oleh siswa dan guru. (Sugiyono, 2017: 137). Pengisian angket, dan dokumentasi kegiatan pembelajaran.

\section{HASIL DAN PEMBAHASAN}

Pada pertemuan pertama guru menggunakan metode pembelajaran simulasi digital, sedang media yang digunakan adalah LCD Proyektor, mikrofon dan software desain prsentasi video.

Tabel 1. Hasil Tes Belajar Siswa Siklus I

\begin{tabular}{|c|c|c|c|c|c|}
\hline \multirow[b]{2}{*}{ No } & \multirow[b]{2}{*}{ Nilai } & \multicolumn{2}{|c|}{ Pertemuan I } & \multicolumn{2}{|c|}{ Pertemuan II } \\
\hline & & $\begin{array}{c}\text { Freku } \\
\text { ensi }\end{array}$ & $\begin{array}{c}\text { Persent } \\
\text { ase }\end{array}$ & $\begin{array}{c}\text { Freku } \\
\text { ensi }\end{array}$ & $\begin{array}{c}\text { Persentas } \\
\mathrm{e}\end{array}$ \\
\hline 1 & 90 & 7 & 3,21 & 8 & 2,81 \\
\hline 2 & 85 & 4 & 5,31 & 3 & 7,08 \\
\hline 3 & 80 & 6 & 3,33 & 5 & 4,00 \\
\hline 4 & 75 & 5 & 3,75 & 6 & 3,12 \\
\hline \multirow[t]{2}{*}{5.} & 70 & 5 & 3,50 & 5 & 3,50 \\
\hline & & 27 & $19.97 \%$ & 27 & $20,51 \%$ \\
\hline Rat & & & 0 & & 75 \\
\hline
\end{tabular}

Dari 27 siswa kelas $\mathrm{X}$ TKJ ini yang mendapat nilai tertinggi 7 orang dengan nilai 90 , kemudian yang mendapat nilai 85 ada 4 orang, nilai 806 orang, nilai 75 ada 5 orang, dan yang mendapat nilai 70 ada 5 orang siswa. Alhamdulillah, lebih dari seperempat siswa berhasil mendapat nilai baik.

Kemudian dari lembar observasi kegiatan mandiri siswa ada 17 siswa yang mendapat nilai 75 keatas, sedangkan yang 10 siswa belum mendapat nilai diatas 75 keatas.

Pada pertemuan kedua, guru menggunakan metode yang sama agar tujuan pembelajaran dan materi belajar berjalan secara baik ketika guru menjelaskan materi dan siswa memahami materi yang disampaikan guru.

Kemudian dari lembar observasi, kegiatan mandiri siswa ada tambahan nilai mandiri, kecuali pada aspek pengamatan waktu yang terjadi dalam penurunan nilaisemua siswa. Hal ini karena pertemuan yang kedua dan pertama waktu dalam pembelajaran tidak jauh beda.

Kemudian dari hasil tes masing-masing siswa juga mengalami penambahan nilai pada setiap kegiatan belajar walaupun sedikit jauh. Hal ini disebabkan dalammetode yang digunakan guru sama tetapi waktu dengan waktu yang berbeda.

Tabel 2. Hasil Tes Belajar Siklus II 


\begin{tabular}{cccccc}
\hline No & Nilai & \multicolumn{2}{c}{ Pertemuan III } & \multicolumn{2}{c}{ Pertemuan IV } \\
\cline { 3 - 6 } & $\begin{array}{c}\text { Freku } \\
\text { ensi }\end{array}$ & $\begin{array}{c}\text { Persent } \\
\text { ase }\end{array}$ & $\begin{array}{c}\text { Freku } \\
\text { ensi }\end{array}$ & $\begin{array}{c}\text { Persentas } \\
\text { e }\end{array}$ \\
\hline 1 & 90 & 8 & 2,25 & 10 & 2,81 \\
\hline 2 & 85 & 2 & 4,25 & 5 & 10,62 \\
\hline 3 & 80 & 5 & 6,66 & 3 & 4,00 \\
\hline 4 & 75 & 8 & 4,68 & 4 & 2,34 \\
\hline 5. & 70 & 4 & 3,50 & 5 & 4,37 \\
\hline & & 27 & $21,34 \%$ & 27 & $24,14 \%$ \\
\hline
\end{tabular}

Rata-rata nilai tes formatif pada pertemuan 3 diperoleh nilai 79, ini berarti sudah berada dalam ketuntasan belajar dan semua siswa yang berjumlah 27 orang mendapat nilai minimal 75 , hal ini berarti secara individu maupun secara klasikal belum mencapai $100 \%$, belum mencapai ketuntasan belajar. Pertemuan ke empat ada pada peningkatan yaitu menjadi 89 .

Adapun metode yang digunakan dalam memulai pembelajaran simulasi digital itu sama dengan pertemuan pertama. Alhamdulillah pada pertemuan ketiga ini nilai siswa sudah mencapai nilai yang baik dalam pembelajaran, baik nilai secara klasikal maupun individu. Nilai individu siswa yang tertinggi adalah nilai 90 ada 7 orang sedang nilai terendah siswa adalah 70 ada 5 orang.

Adapun pada pertemuan keempat materi yang disampaikan mengenai branding sama dengan materi pertemuan ketiga. Metode yang digunakan dalam branding adalah alatalat yang mencakup dengan promosikan barang dalam waktu 1 x 40 menit.

Dalam pertemuan keempat ini Alhamdulillah nilai semua siswa mendapat peningkatan, baik secara klasikal maupun mandiri. Namun pada bagian aspek pemanfaatan waktu nilai semua siswa mengalami penurunan dibandingkan nilai pemanfaatan waktu pada pertemuan ketiga, karena siswa masih saja mengabaikan waktu yang singkat itu.

Kemudian dalam hal menjelaskan materi presentasi video dan branding juga mengalami peningkatan, yakni $75 \%$ dan $85 \%$ siswa sudah menjelaskan sesuai yang diharapkan. Hal ini disebabkan karena materi yang dijelaskan masih kurang dan harus diulang kembali materi yang sudah dibahas dalam pertemuan yang lalu.

\section{KESIMPULAN}

Berdasarkan hasil penelitian yang didapatkan data pada kondisi awal kelas X TKJ di SMK Swasta Harapan Bandar Pulo, Kecamatan Batang Serangan memiliki motivasi belajar kurang baik dalam mengikuti pembelajaran Simulasi Digital (Simdig) kurang baiknya motivasi belajar siswa sehingga pada kondisi awal tersebut belum mencapai indikator keberhasilan dalam penelitiantindakan kelas ini.

Motivasi belajar siswa dengan menggunakan metode pembelajaran simulasi digital ini yaitu guru meperlihatkan media pembelajaran yang telah disiapkan, siswa mengamati hasil penjelasan yang disampaikan guru, siswa bersama guru bertanya jawab tentang pembelajaran simulasi digital dengan materi yang disampaikan guru. Salah satu siswa menjelaskan materi tentang simulasi digital agar yang lain ikut serta untuk maju ke depan kelas. Dengan adanya media pembelajaran simulasi digital, maka pembelajaran akan lebih menarik dibandingkan tanpa adanya gambar atau media yag dilakukan guru supaya dapat memperjelas materi yang ingin disampaikan seorang guru agar tidak monoton dan menarik perhatian belajar siswa.

Hal ini dapat dilihat dari motivasi belajar siswa setelah dilakukannya tindakan kelas. Siswa lebih menjadi tekun dalam mengerjakan tugas yang diberikan guru, ulet menghadapi kesulitan, dapat mempertahankan pendapatnya, senang bekerja secara mandiri, dan dapat mengerjakan soal-soal yang sulit menjadi akan mudah ketika siswa tersebut termotivasi mengerjakannya. 
Berdasarkan hasil penelitian tindakan kelas, maka dapat disimpulkan bahwapenggunaan metode pembelajaran simulasi digital dapat meningkatkan motivasi belajar siswa kelas X TKJ di SMK Swasta Harapan Bandar Pulo. Hal ini dibuktikan dari analisis deskriptif presntase pada kondisi awal motivasi belajar siswa sebesar 19,97\%, pada siklus I Di kategorikan rendah, kemudian setelah diberikan tindakan dalam metode simulasi digital pada siklus 3 meningkat menjadi 21, 34\% kategori sedang lalu pada siklus ke empat meningkat lagi menjadi 24,14\% dikategorikan cukup.

\section{DAFTAR PUSTAKA}

Aqib, Zainal, (2009); Penelitian Tindakan Kelas, Bandun: CV, Yrama Widya.

Arikunto, Suharsimi, (2012); Penelitian Tindakan Kelas, Jakarta; PT Bumi Aksara.

Hamzah, Uno B, (2010); Teori Motivasi dan Pengukurannya, Jakarta: PT Bumi Aksara.

Lutfiyani, Gesti, (2016); Upaya Meningkatkan Motivasi Belajar Siswa Melalui Penggunaan,Edia Puzzle Pada Mata Pelajaran Ilmu Pengetahuan Alam Di Kelas III Sekolah Dasar Negeri Kepek Kulon Progo; Skripsi; Universiitas Negeri Yogyakarta.

Sanjaya, Wina, (2018); Strategi Pembelajaran Berorientasi Standar Proses Pendidikan, Jakarta: Kencana PrenadaMedia Group.

Sardiman, AM, (2017); Interaksi \& Motivasi Belajar Mengajar, Jakarta: PT Rajagrafindo Persada.

Sugiyono, (2017); Metode Penelitian Kuantitatif, Kualitataif, dan $R \& D$, Bandung: Alfabeta.
Sumiati, Dra, (2018); Metode Pembelajaran, Bandung: CV Wacana Prima.

Wahyudi, M. Dian. 2015. Hubungan Persepsi Guru Tentang Perilaku Kepemimpinan Transformasional Kepala Sekolah Dan Iklim Komunikasi Dengan Kinerja Guru SD Negeri Di Kecamatan Binjai Timur Kota Binjai. Jurnal Pendidikan dan Kepengawasan, Vol 2 No. 1, April 2015. Jurnal Pendidikan dan Kepengawasan, Vol 2 No. 1.

Widodo, Rahman, (2011); Peningkatan Motivasi Dan Prestasi Belajar Siswa Melalui Metode Simulasi Pada Mata Pelajaran Elektronika Digital Di SMK Negeri Mondokon; Skripsi: Fakultas Teknik Universitas Negeri Yokyakarta. 